\title{
Biodiesel Production Using Modified Direct Transesterification by Sequential Use of Acid-Base Catalysis and Performance Evaluation of Diesel Engine Using Various Blends
}

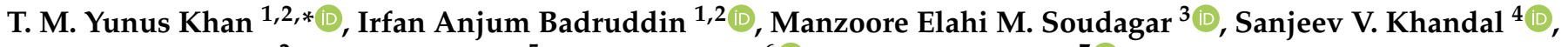 \\ Sarfaraz Kamangar ${ }^{2}$, Imran Mokashi ${ }^{5}$, M. A. Mujtaba ${ }^{6}{ }^{(0)}$ and Nazia Hossain ${ }^{7}$ \\ 1 Research Center for Advanced Materials Science (RCAMS), King Khalid University, \\ Abha 61413, Saudi Arabia; magami.irfan@gmail.com \\ 2 Department of Mechanical Engineering, College of Engineering, King Khalid University, \\ Abha 61421, Saudi Arabia; sarfaraz.kamangar@gmail.com \\ 3 Department of Mechanical Engineering, School of Technology, Glocal University, Saharanpur 247121, India; \\ me.soudagar@gmail.com \\ 4 Department of Mechanical Engineering, Sanjay Ghodawat University, Kolhapur 416118, India; \\ sanjeevvkhandal@gmail.com \\ 5 Department of Mechanical Engineering, Bearys Institute of Technology, Mangalore 574153, India; \\ mokashi782@gmail.com \\ check for \\ updates \\ Citation: Khan, T.M.Y.; Badruddin, \\ I.A.; Soudagar, M.E.M.; Khandal, S.V.; \\ Kamangar, S.; Mokashi, I.; Mujtaba, \\ 6 Department of Mechanical Engineering, Faculty of Engineering, University of Malaya, \\ Kuala Lumpur 50603, Malaysia; m.mujtaba@uet.edu.pk \\ 7 School of Engineering, RMIT University, Melbourne, VIC 3000, Australia; bristy808.nh@gmail.com \\ * Correspondence: yunus.tatagar@gmail.com
} M.A.; Hossain, N. Biodiesel Production Using Modified Direct Transesterification by Sequential Use of Acid-Base Catalysis and Performance Evaluation of Diesel Engine Using Various Blends. Sustainability 2021, 13, 9731. https:// doi.org/10.3390/su13179731

\section{Academic Editors: Juan}

José Hernández Adrover and Barry D. Solomon

Received: 5 July 2021

Accepted: 27 August 2021

Published: 30 August 2021

Publisher's Note: MDPI stays neutral with regard to jurisdictional claims in published maps and institutional affiliations.

Copyright: (c) 2021 by the authors. Licensee MDPI, Basel, Switzerland. This article is an open access article distributed under the terms and conditions of the Creative Commons Attribution (CC BY) license (https:// creativecommons.org/licenses/by/ $4.0 /)$.

\begin{abstract}
Biodiesel is a seemingly suitable alternative substitute for conventional fossil fuels to run a diesel engine. In the first part of the study, the production of biodiesel by modified direct transesterification (MDT) is reported. An enhancement in the biodiesel yield with a considerable reduction in reaction time with the MDT method was observed. The required duration for diesel and biodiesel blending was minimized including glycerol separation time from biodiesel in the MDT method. The development in the automotive sector mainly focuses on the design of an efficient, economical, and low emission greenhouse gas diesel engine. In the current experimental work Ceiba pentandra/Nigella sativa and diesel blends (CPB10 and NSB10) were used to run the diesel engine. A variety of approaches were implemented to improve the engine performance for these combinations of fuels. The fuel injector opening pressure (IOP) was set at 240 bar, the torriodal re-entrant combustion chamber (TRCC) having a six-hole injector with a $0.2 \mathrm{~mm}$ orifice diameter each, provided better brake thermal efficiency (BTE) with lower emissions compared with the hemispherical combustion chamber (HCC) and trapezoidal combustion chamber (TCC) for both CPB10 and NSB10. CPB10 showed better performance compared with NSB10. A maximum BTE of $29.1 \%$ and $28.6 \%$ were achieved with CPB10 and NSB10, respectively, at all optimized conditions. Diesel engine operation with CPB10 and NSB10 at $23^{\circ} \mathrm{bTDC}$ fuel injection timing, and $240 \mathrm{bar}$ IOP with TRCC can yield better results, close to a diesel run engine at $23^{\circ} \mathrm{bTDC}$ fuel injection timing, and 205 bar IOP with HCC.
\end{abstract}

Keywords: Ceiba pentandra; Nigella sativa; sequential acid-base catalysts; nozzle geometry; combustion chamber shapes; efficient engines

\section{Introduction}

In the perspective of green emissions, biodiesel was regarded as a supplement to diesel as fuel [1,2]. Being a renewable fuel with low emission characteristics, biodiesel production has spiked. Biodiesel is produced by the transesterification of triglycerides with methanol using a catalyst [3]. There are rigorous technological proliferations to make 
biodiesel as a commercial fuel in contrast to diesel. The driving requisites for these reforms are improved production rate, enhanced fuel properties, economical operation, reduction in manufacturing and reaction time, ideal reaction conditions etc. The application of boron trifluoride, an acidic catalyst, and sodium methoxide, a base catalyst, in combination with microalgae by direct transesterification was more effective than their use individually [4]. Khan et al. [5] employed the direct transesterification process for producing biodiesel from five different non-edible feedstocks. They concluded that the method can reduce the reaction time from $5 \mathrm{~h}$ to $2 \mathrm{~h}$ and yield was increased from $2 \%$ to $5 \%$. However, there was no significant changes/improvements in the fuel properties. Further, Khan [6] investigated the effect of the addition of graphene oxide nanoparticles in Neem and Karanja biodiesel synthesized by using a single step direct transesterification method. The addition of $105 \mathrm{ppm}$ of graphene oxide nanoparticles in the biodiesel enhanced the micro-explosion phenomenon of the fuel blends due to a higher surface area of graphene oxide nanoparticles. Thus, increasing the BTE and reducing BSFC, besides reduced emissions for biodieseldiesel-nano blended fuels. The present study is conducted to explore the concept of direct transesterification which implies sequential utilization of acidic and basic catalyst in the production of biodiesel. A modification of the said method was incorporated for effective separation of biodiesel from the mixture to reduce the biodiesel and diesel blending time.

Better power and fuel economy are the desires of the customer. However, stringent emission norms need to be considered while designing higher power output engines with better fuel economy. The influencing parameters such as pressure of fuel injection, compression ratio, timings and duration of injection, impact the performance of a diesel engine and its emission [7]. The emissions such as $\mathrm{HC}, \mathrm{CO}$ and smoke emissions were lowered by the effective compliance of fuel injection pressure (230 bar) and injection timing $\left(26^{\circ} \mathrm{bTDC}\right)$ with a slight increase in NOx [8]. Similar types of results were reported in open literature, stating that biodiesel can limit emissions of $\mathrm{CO}$, hydrocarbons, and particulates conversely to NOx by optimizing injection pressure and injection timing [9-13]. The increase in NOx emissions can be minimized by altering the injection timings and injection pressure [14,15]. Research investigations on the engine performance, combustion and emissions were carried out either considering injection pressure effects [16-19] or the effects of injection timings [20-24]. The combined effect of injection timings and pressure has been studied by very few $[15,25,26]$. In recent years, some researchers reported performance and emission tests on engines using Ceiba pentandra as a biodiesel fuel beside its comparison with other non-edible feedstocks as biodiesel [27-30]. In a review study, authors compared the properties of various oils and biodiesels. The literature specifies the influence on the diesel engine performance with a variety of injection methods adopted [31]. Experiments conducted on Nigella sativa concluded that it can be developed as a feedstock for biodiesel [32,33]. It can be concluded that no study has been conducted using Ceiba pentandra and Nigella sativa as biodiesel fuel to evaluate the effects of the geometry of the nozzle, injection pressure and the shape of the combustion chamber on the diesel engine characteristics.

In the present research, a new concept is introduced known as the modified direct trans-esterification (MDT); in this technique the yield of the final product viz. biodiesel is higher and reduces the reaction time, and washing and separation methods are enhanced compared with conventional biodiesel production techniques. Furthermore, an effort was made to improve the performance and reduce emissions by a modified six-hole fuel injector with a hole diameter of $0.2 \mathrm{~mm}$, an injector opening pressure of $240 \mathrm{bar}$ with a modified toroidal re-entrant piston bowl geometry combustion chamber.

\section{Materials and Methods}

The Ceiba pentandra (Kapok) and Nigella sativa (black cumin) crude oils were purchased from Java, Indonesia, and Bangladesh, respectively. The other chemical reactants such as boron trifluoride $(\mathrm{BF} 3)$, methanol, sodium methoxide $(0.1 \mathrm{~N})$, spectroscopic grade petroleum ether $60-80{ }^{\circ} \mathrm{C}, \mathrm{H}_{2} \mathrm{SO}_{4}, \mathrm{KOH}$, anhydrous sodium sulphate $\left(\mathrm{Na}_{2} \mathrm{SO}_{4}\right)$, etc. were 
locally bought at Kuala Lumpur, Malaysia. The background of both feedstocks was provided in our previous work [33].

\subsection{Production of Biodiesel Using Direct Transesterification (DT)}

The usual method of esterification-transesterification has acute drawbacks of delayed duration of reaction and reduced yield of biodiesel. Glycerine separation from biodiesel is another disadvantage associated with the esterification-transesterification method. These vital reasons motivated the devising of a direct transesterification, which involves the sequential use of acidic and basic catalysts. An intense detailing of which was discussed in our earlier research work [5].

The DT method had some disadvantages especially while using petroleum ether. The method described was not economical and was consuming more time while evaporation and condensation of petroleum ether occurred. It was decided to avoid usage of petroleum ether itself. After a reaction time of $120 \mathrm{~min}$ an upper methyl ester layer with fatty acids and a glycerol lower layer were produced in the reaction mixture. Next, distilled water $(1 \mathrm{~L})$ was used to wash the reaction mixture, without using petroleum ether. The biodiesel was separated from water. A total of $250 \mathrm{gms}$ of sodium sulphate $\left(\mathrm{Na}_{2} \mathrm{SO}_{4}\right)$ was added to remove the moisture contents. The mixture was filtered. Finally, biodiesel was obtained. However, in this method the separation of biodiesel from water was difficult and biodiesel yield was not appreciable. There was wastage of biodiesel during separation. Hence, the method further improved with some modifications. The details of the modified method are explained in Section 2.2.

\subsection{Modified Direct Transesterification (MDT)}

In the modified direct transesterification method, instead of petroleum ether, direct diesel was mixed. By using the diesel in place of petroleum ether, usage of petroleum ether was avoided. Hence, the evaporation and condensation time of petroleum ether was eliminated. It was known from the DT method that the biodiesel yield was $92 \%$ for NSME and 93\% for CPME. Knowing the yield of biodiesel in the reaction mixture, the quantity of biodiesel present in the mixture was determined. Now, a proportionate volume of diesel was added to the reaction mixture instead of petroleum ether to form the B10 biodiesel-diesel blend. The reaction mixture, which contains $\mathrm{B} 10$ biodiesel-diesel blend, was separated from the glycerol layer. A total of $100 \mathrm{gms}$ of potassium carbonate $\left(\mathrm{K}_{2} \mathrm{CO}_{3}\right)$ was added to the biodiesel-diesel blend to minimize the formation of moisture contents. The cleaning and filtering processes remained the same as in case of DT method. It is important to note that the MDT method produces the required biodiesel-diesel blends directly by mixing diesel into the reaction mixture containing biodiesel. However, this was not the case with the DT method. The DT method required the biodiesel be separated first from the reaction mixture and then cleaned. Further, the required quantity of diesel was added to obtain the required biodiesel-diesel blends.

The encompassed MDT method substantially removes the problems of evaporation, condensation, biodiesel-diesel blending time and segregation time involved with the use of petroleum ether. The fuel properties of the B10 biodiesel-diesel obtained by DT and MDT exhibited no significant variation.

\section{Experimental Procedure and Set Up Used}

The engine testing was carried out for the biodiesel-diesel blend $(10 \%)$ produced by the MDT method of Nigella sativa and Ceiba pentandra feedstocks. Nigella sativa is a new feedstock which deserves to be tested, on the engine to establish its authority as a potential biodiesel feedstock. The other oil considered for engine testing is Ceiba pentandra because there is not much work published on this oil with respect to its behavior in the engine due to variations in injection parameters. Four stroke single cylinder diesel engine specifications are specified in Table 1. 
Table 1. Diesel engine specification.

\begin{tabular}{ccc}
\hline S1. No. & Parameters & Specification \\
\hline 1 & Type & TV1 (Kirlosker make) \\
2 & Nozzle opening pressure & 200-250 bar \\
3 & Number of cylinders & Single cylinder \\
4 & Number of strokes & Four stroke \\
5 & Cylinder diameter (bore) & $87.5 \mathrm{~mm}$ \\
6 & Rated power & $5.2 \mathrm{~kW}(7 \mathrm{HP})$ at $1500 \mathrm{rpm}$ \\
7 & Compression ratio & $17.5: 1$ \\
8 & Stroke length & $110 \mathrm{~mm}$ \\
\hline
\end{tabular}

Experiments for various parameters were conducted as shown in Figure 1. Smoke meter and exhaust gas analyzer were incorporated to measure exhaust emissions. Further performance and emission testing of the engine were carried out for the biodiesel-diesel blends of Ceiba pentandra and Nigella sativa. The biodiesel-diesel blends of CPB10 and NSB10 were obtained from the modified direct transesterification method. Owing to similar fuel properties in contrast with diesel, $10 \%$ blends of Ceiba pentandra and Nigella sativa with diesel were selected. The experiments were conducted at the rated speed of $1500 \mathrm{rpm}$. Measurements were noted at stable operating conditions of the engine and exhaust gas analyzer. The DELTA $1600 \mathrm{~S}$ exhaust gas analyzer shown in Figure 2 works on nondispersive infrared technology (NDIR). Exhaust emissions such as CO, HC as n-Hexane equivalent: $\mathrm{C}_{6} \mathrm{H}_{14}, \mathrm{CO}_{2}$ were recorded by allowing an infrared light to pass through the sample cell up to the optical block. The sample cell temperatures were controlled so that a measurement compensation for the sample gas temperature and pressure variances was provided. Infrared rays penetrate through (four optical band pass), each filter for the target gases (one filter being the reference filter). Voltage proportional to light intensity were obtained through four pyroelectric detectors that collect light passing through these filters and then digital values were obtained with ADC. The microprocessor samples the $\mathrm{ADC}$ and thereby provides the required data that are $\mathrm{HC}$ in $\mathrm{ppm}$ and $\mathrm{CO}$ in $\%$ volume. Electrochemical (fuel cell) sensors provide an electrical response proportional to oxygen and $\mathrm{NO}_{\mathbf{X}}$ concentration. Sensors are self-powered, diffusion limited, metal air battery type and consist of an anode, electrolyte, and an air cathode. Smoke level was obtained with a Hartridge smoke meter [Figure 3]. It consists of two dimensionally similar tubes which are optically identical. Clean air is drawn into the reference tube through a damper connected to an air blower. The other tube (smoke) is connected to a pipe where the smoke is to be measured. The inlet manifold consists of a temperature sensor and moisture trap besides a pressure-controlled outlet. Smoke level in the sample gas was compared with clean air by recording a reading through the clean air tube to set the zero. After this, the light and photoelectric cell were moved through the smoke tube. Both values were compared.

The engine was fueled with diesel, CPB10 and NSB10. Diesel was run with ideal injection timing and pressure of $23^{\circ} \mathrm{bTDC}$ and 205 bar. The engine was operated with CPB10 and NSB10 at an IOP range varying 220-250 bar keeping a normal fuel injection timing of $23^{\circ} \mathrm{bTDC}$. The fuel injection pressure was set using the fuel injection tester provided in Figure 4.

At every crank angle the HRR was tabulated employing the first law analysis of mean pressure against the variation in crank angle acquired considering 100 cycles. An $\mathrm{AD}$-converter was used to record the sensor signals, indicating the pressure and TDC position of the cylinder. Table 2 provides information about measurement accuracy and variations in the calculated parameters. 


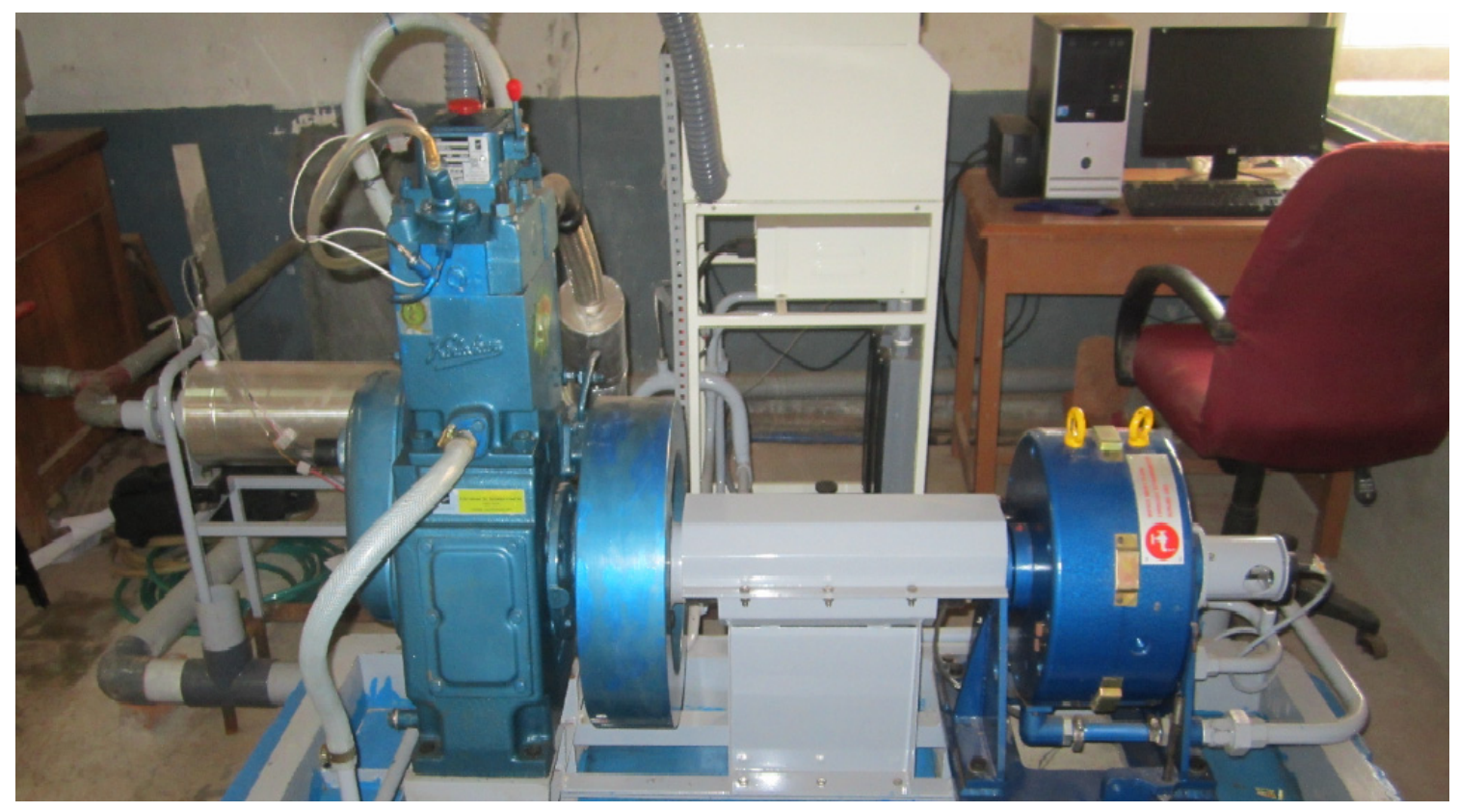

Figure 1. Test rig of compression ignition (CI) engine.

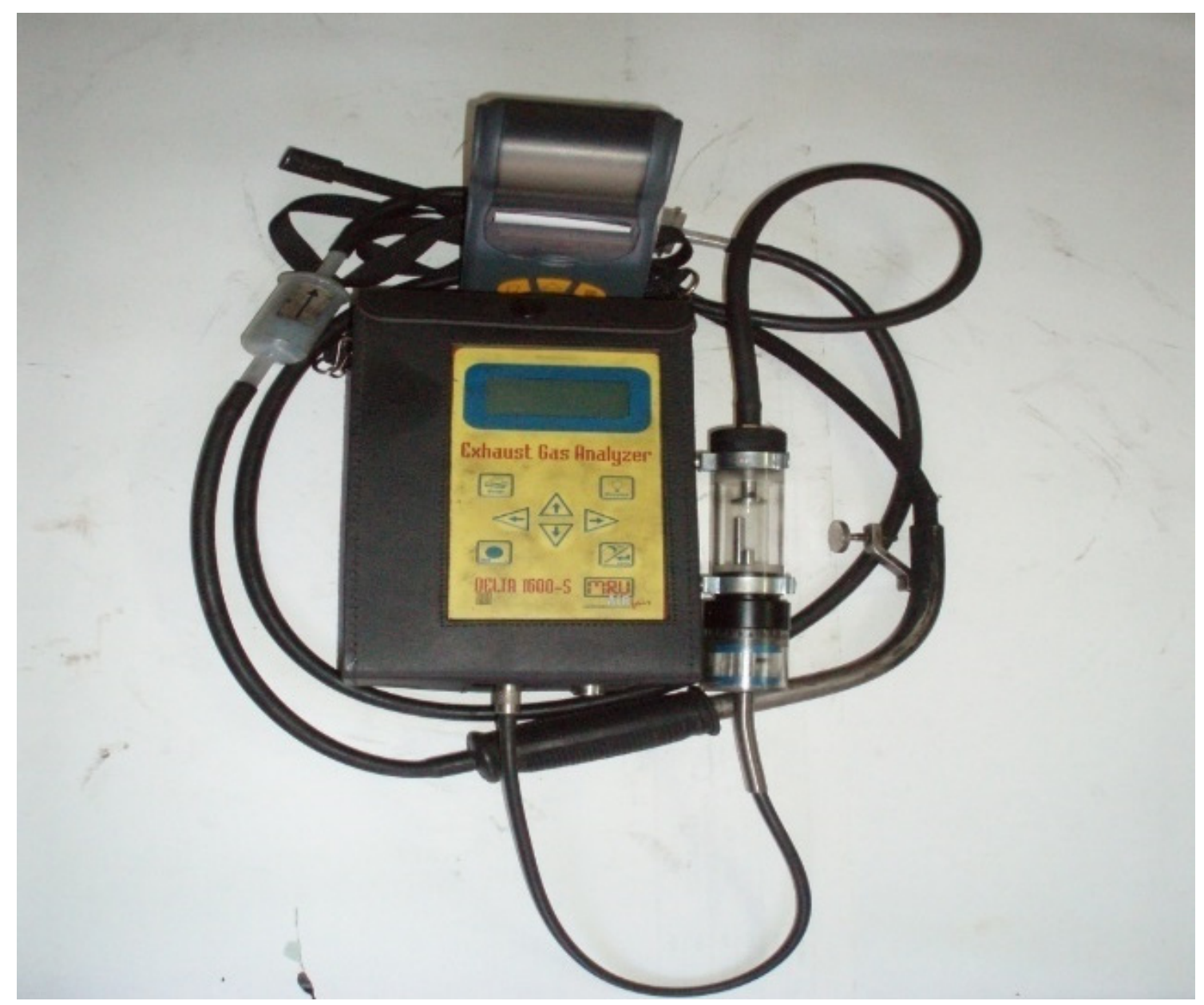

Figure 2. Exhaust gas analyzer (EGA). 


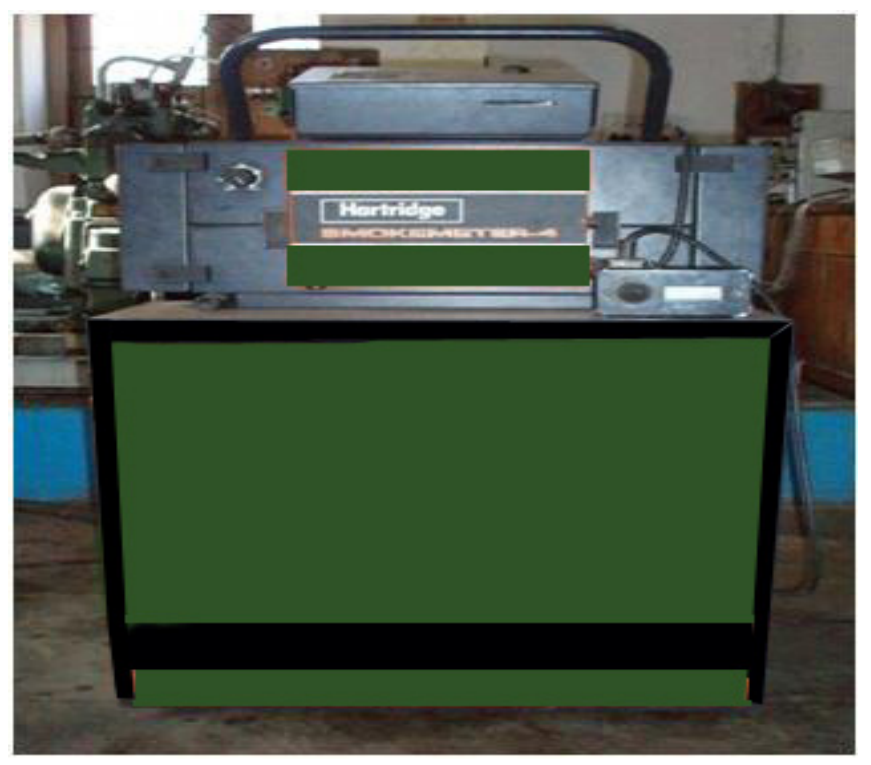

Figure 3. Hartridge smoke meter.

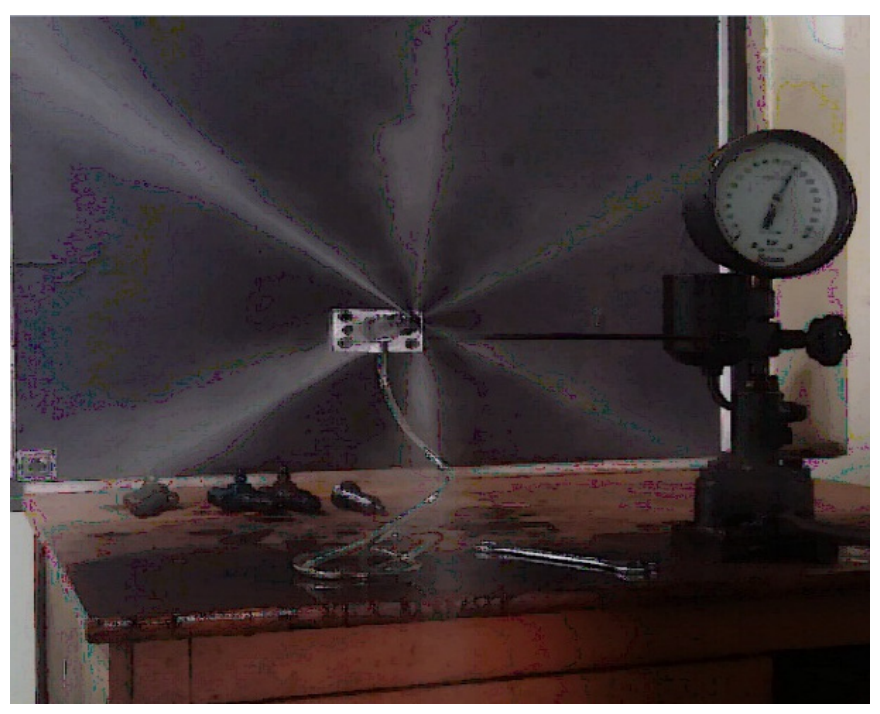

Figure 4. Fuel injector tester.

Table 2. Measurement accuracy and calculated parameters variation.

\begin{tabular}{cc}
\hline Measured Variable & Accuracy $( \pm)$ \\
\hline Load, N & 0.1 \\
Engine speed, rpm & 2 \\
Temperature, ${ }^{\circ} \mathrm{C}$ & 2 \\
\hline Measured variable & Uncertainty $(\%)$ \\
\hline Smoke & \pm 1.2 \\
HC & \pm 1.2 \\
CO & \pm 2.4 \\
NOx & \pm 5 \\
\hline Calculated parameters & Uncertainty $(\%)$ \\
\hline BTE, $(\%)$ & \pm 1.3 \\
\hline
\end{tabular}




\section{Results and Discussions}

The MDT method was applied to two non-edible feedstocks of Nigella sativa and Ceiba pentandra. The method was used to obtain the B10 blend of both respective biodiesels. Table 3 provides the fuel properties of B10 Nigella sativa (NSB10) and Ceiba pentandra (CPB10). The properties obtained by MDT applied to Nigella sativa and Ceiba pentandra specifically display scarce differences in the properties of fuel produced by DT and MDT methods. Thus, it can be confidently said that the MDT and DT are well-qualified to be adopted as biodiesel production techniques.

Table 3. Properties of biodiesel-diesel blend B10 fuel (MDT).

\begin{tabular}{cccc}
\hline Fuel Properties & NSB10 & CPB10 & Diesel \\
\hline Calorific value $(\mathrm{kJ} / \mathrm{kg})$ & 44,890 & 44,904 & 45,369 \\
At $40{ }^{\circ} \mathrm{C}$, Kinematic viscosity $\left(\mathrm{mm}^{2} / \mathrm{s}\right)$ & 3.655 & 3.6568 & 3.6056 \\
At $40{ }^{\circ} \mathrm{C}$, Dynamic viscosity $(\mathrm{mPa} . \mathrm{s})$ & 3.0535 & 3.0636 & 3.0095 \\
Flash point $\left({ }^{\circ} \mathrm{C}\right)$ & 85.7 & 87.6 & 81.5 \\
At $40{ }^{\circ} \mathrm{C}$, Density $(\mathrm{g} / \mathrm{cc})$ & 0.8441 & 0.8377 & 0.8347 \\
At $110{ }^{\circ} \mathrm{C}$, Oxidation stability $(\mathrm{h})$ & 10.25 & 4.98 & $\mathrm{~N} / \mathrm{R}$ \\
CFPP $\left({ }^{\circ} \mathrm{C}\right)$ & 7 & 5 & 0 \\
Cloud point $\left({ }^{\circ} \mathrm{C}\right)$ & 7 & 7 & 7 \\
\hline
\end{tabular}

A CI engine with a 17.5 compression ratio and $1500 \mathrm{rpm}$ rated speed, powered with CPB10 and NSB10, was used in the experimental study. An injector with three holes, each of $0.3 \mathrm{~mm}$ diameter was incorporated in the initial experimentation.

\subsection{Injector Opening Pressure (IOP) Effect on the CI Engine Performance}

To obtain the best IOP for the maximum BTE, the diesel engine was run with different IOP ranging within 220-250 bar in increments of 10 bar at various brake power (BP). The normal combustion chamber (HCC) was used.

\section{Engine Brake Thermal Efficiency}

Figures 5 and 6 show the IOP variation effect at different loads on the CI engine BTE. At the IOP of 240 bar, the BTE achieved was highest. Better fuel atomization and mixing with air can be attributed for the improved combustion resulting in high BTE [17,34]. Wall wetting can be the reason for the lower BTE reported at the IOP of 250 bar. Thus, for the diesel engine to run on CPB10 and NSB10, an optimum BTE can be achieved at the IOP of 240 bar. Henceforth, IOP of 240 bar will be used in experimental work.

\subsection{Number of Nozzle Holes and Their Orifice Diameter Effect on the Diesel Engine Performance}

The effect of the number of nozzle holes and their orifice diameters on the performance of the diesel engine was studied considering six nozzle holes with an orifice diameter range $0.2 \mathrm{~mm}, 0.25 \mathrm{~mm}$ and $0.3 \mathrm{~mm}$. At a load capacity of $80 \%$ the results obtained were compared with those achieved using three, four and five nozzle holes, each with $0.3 \mathrm{~mm}$ orifice diameter.

\section{Engine Brake Thermal Efficiency}

The BTE variation at a load of $80 \%$ using an injector with six holes and a variety of orifice diameters is represented by Figure 7 . The $0.2 \mathrm{~mm}$ orifice diameter of a six-hole nozzle was witnessed to provide higher BTE in comparison with other setups. The appropriate reason for a spike in BTE can be the improved mixing of the air-fuel and proper combustion of the same [35]. Another critical review can be the less wetting of combustion chamber walls, owing to the reduced mass flow rate of the fuel per hole. Contrary to diesel, CPB10 exhibited $28.1 \%$ and NSB10 showed $27.5 \%$ BTE. 


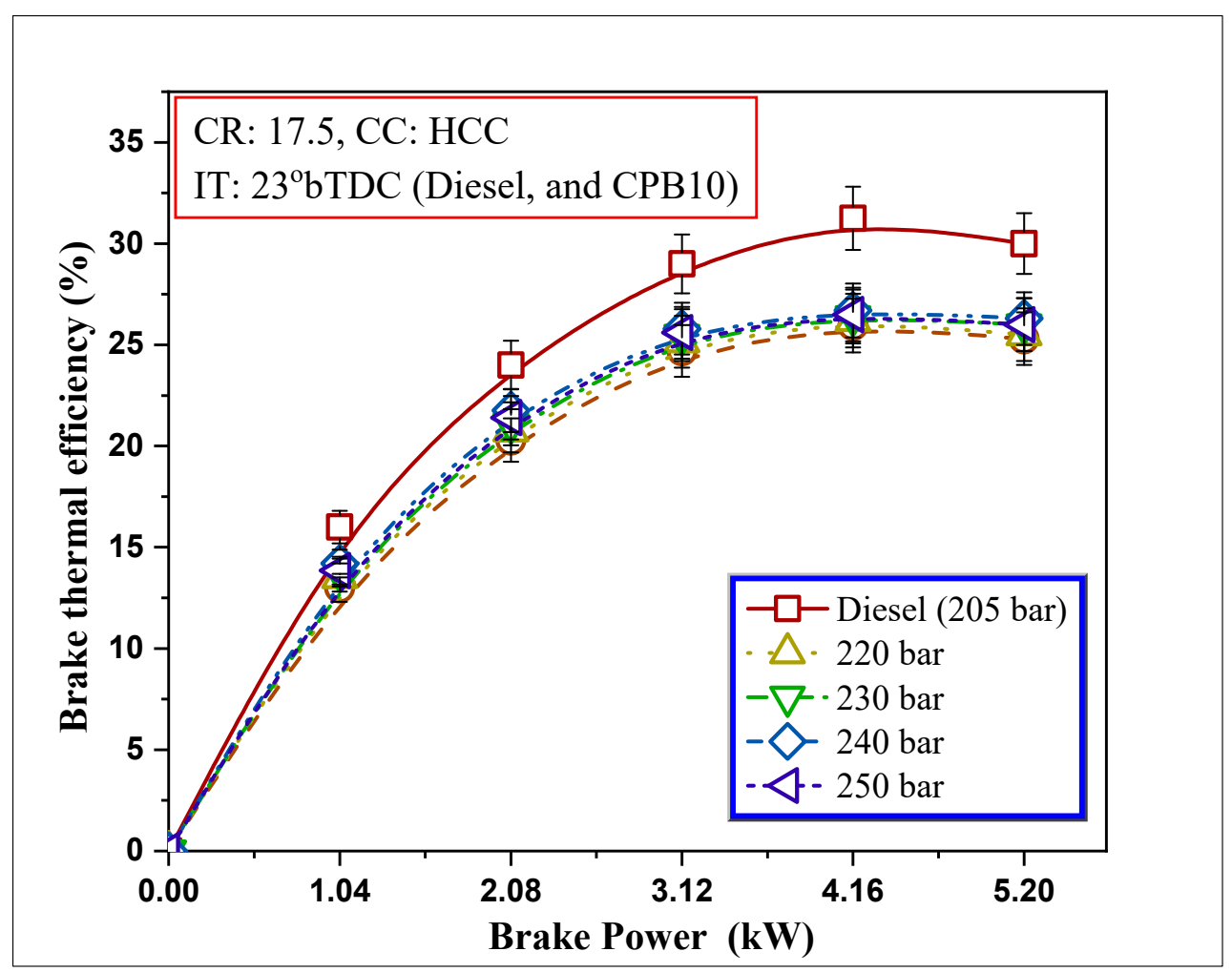

Figure 5. IOP and BP effect on the BTE of CI engine run on CPB10 fuel.

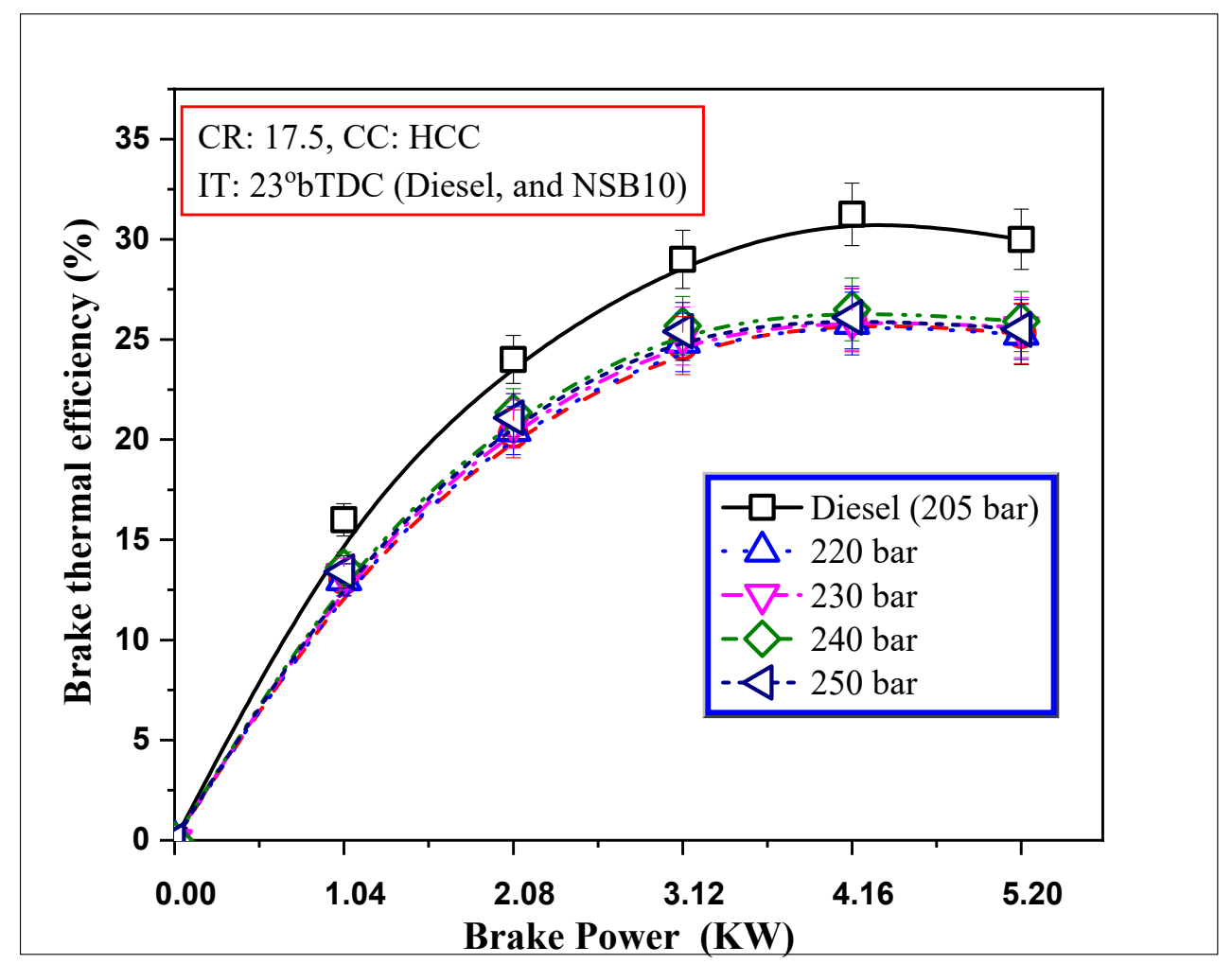

Figure 6. IOP and BP effect on the BTE of CI engine run on NSB10 fuel. 


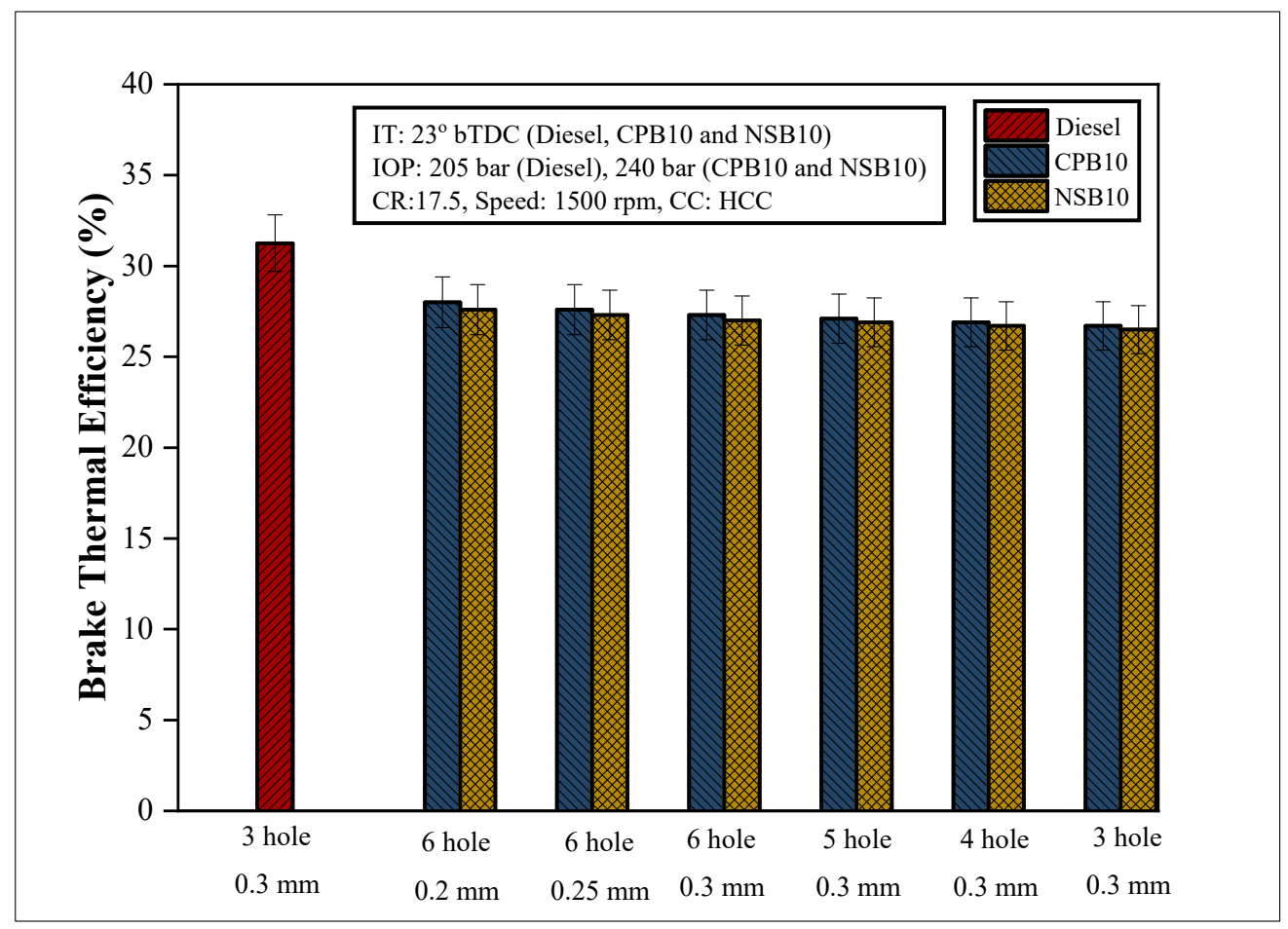

Figure 7. Number of nozzle holes and their orifice size effect on BTE at $80 \%$ load.

\subsection{Shapes Effect on the Performance of Diesel Engine Driven by CPB10 and NSB10}

The experimental results with different CC shapes viz., HCC, trapezoidal combustion chamber (TCC) and TRCC shapes are presented in Figures 8-16. The IOP of 240 bar for blends, and a six-hole nozzle with orifice diameters of $0.2 \mathrm{~mm}$ was utilized for experimentation as the BTE yielded under these conditions was better.

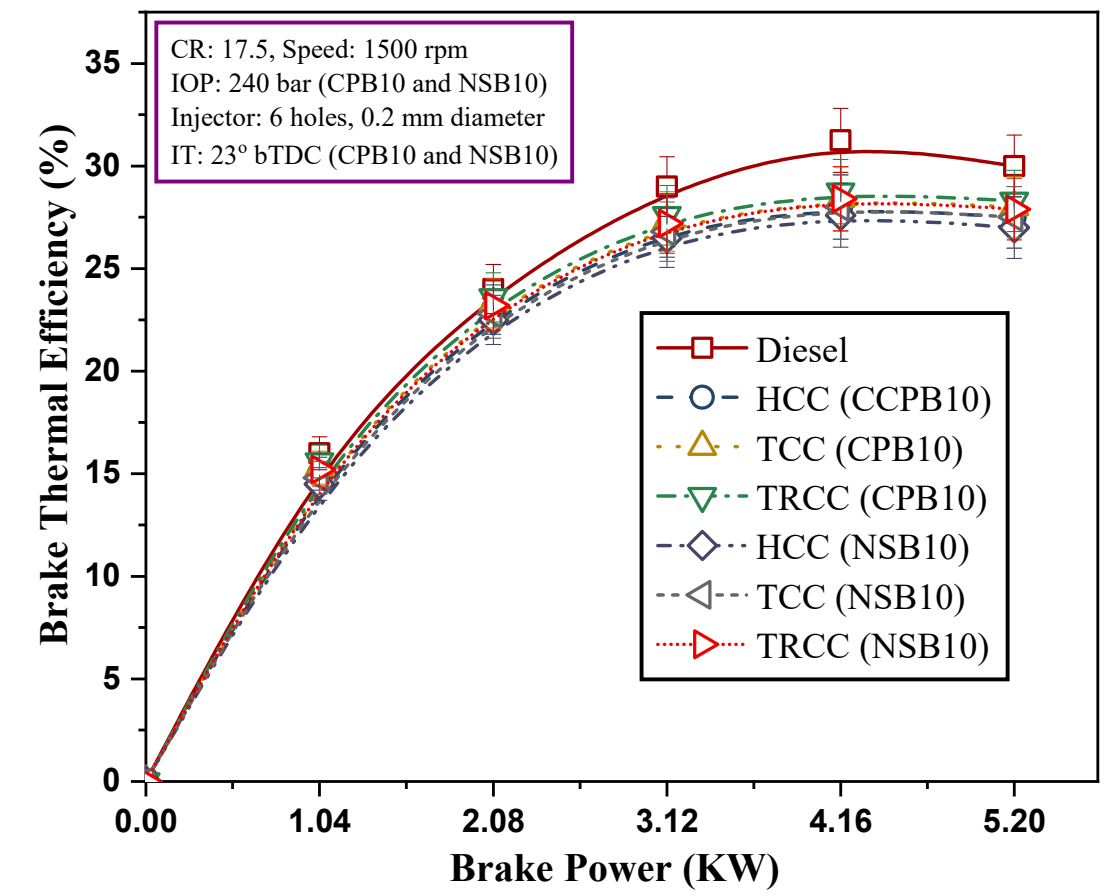

Figure 8. Variations in the engine BTE with various CC shapes and BP. 


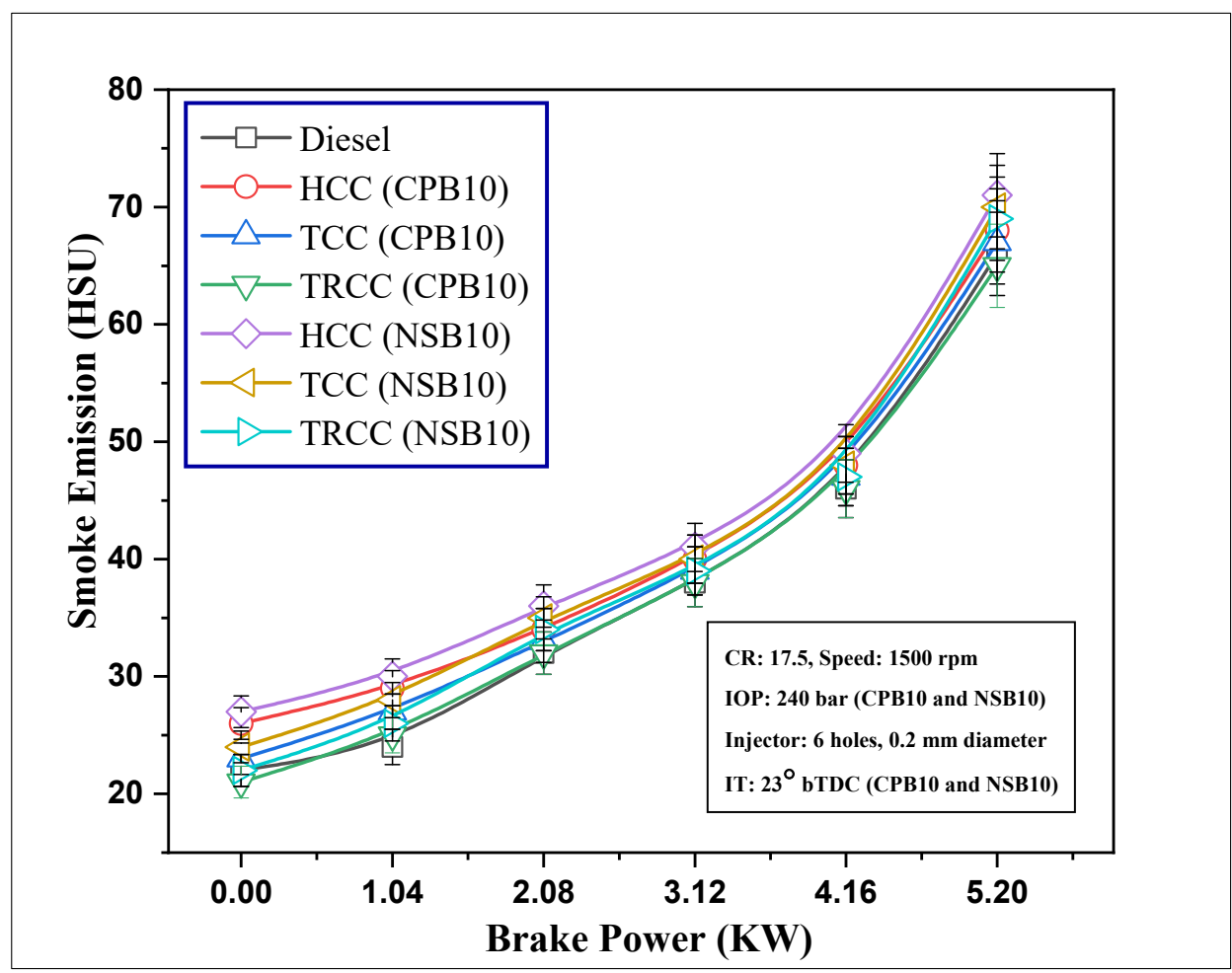

Figure 9. Smoke emission variation at various $\mathrm{CC}$ shapes and BP.

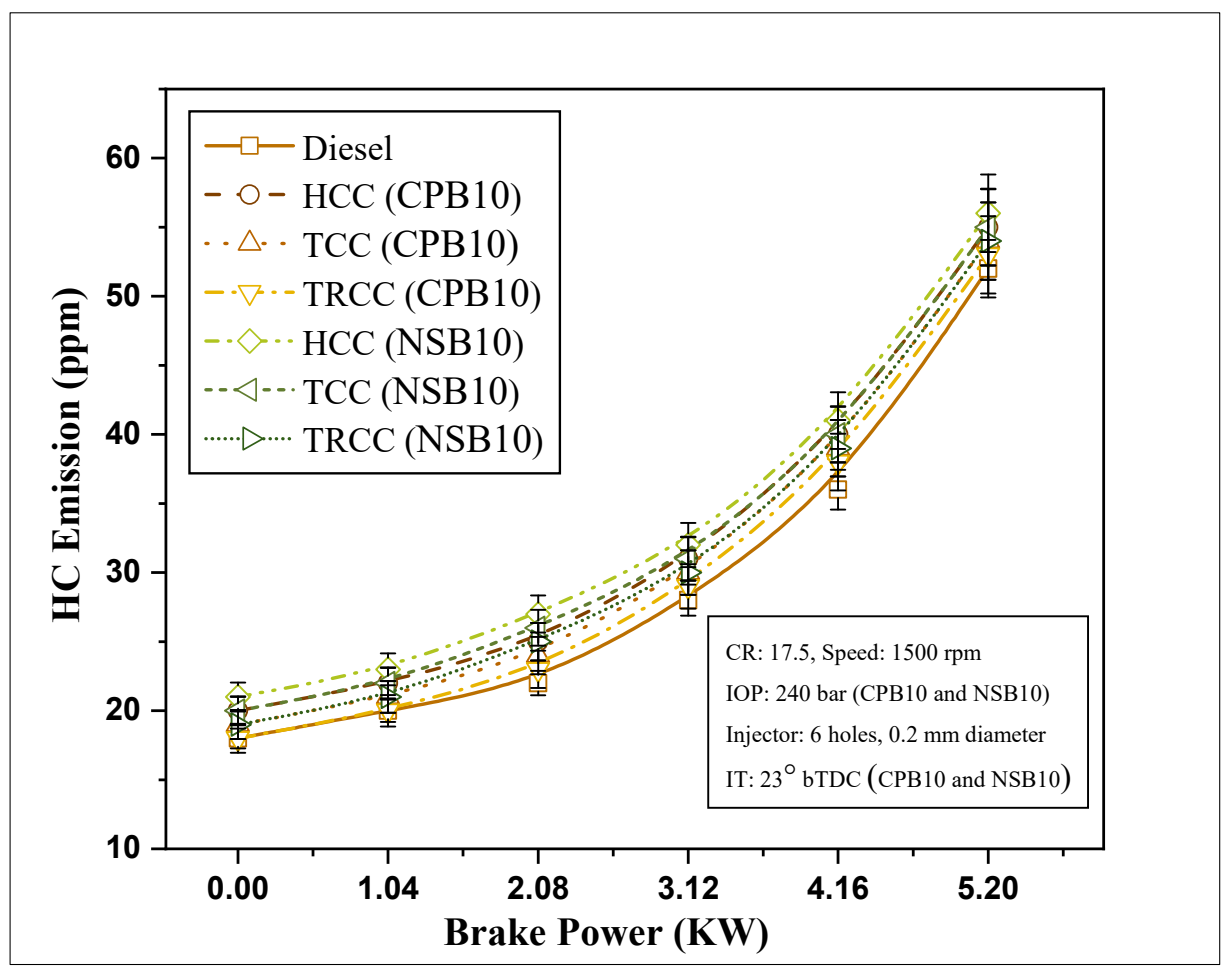

Figure 10. HC Emission variation at various $C C$ shapes and BP. 


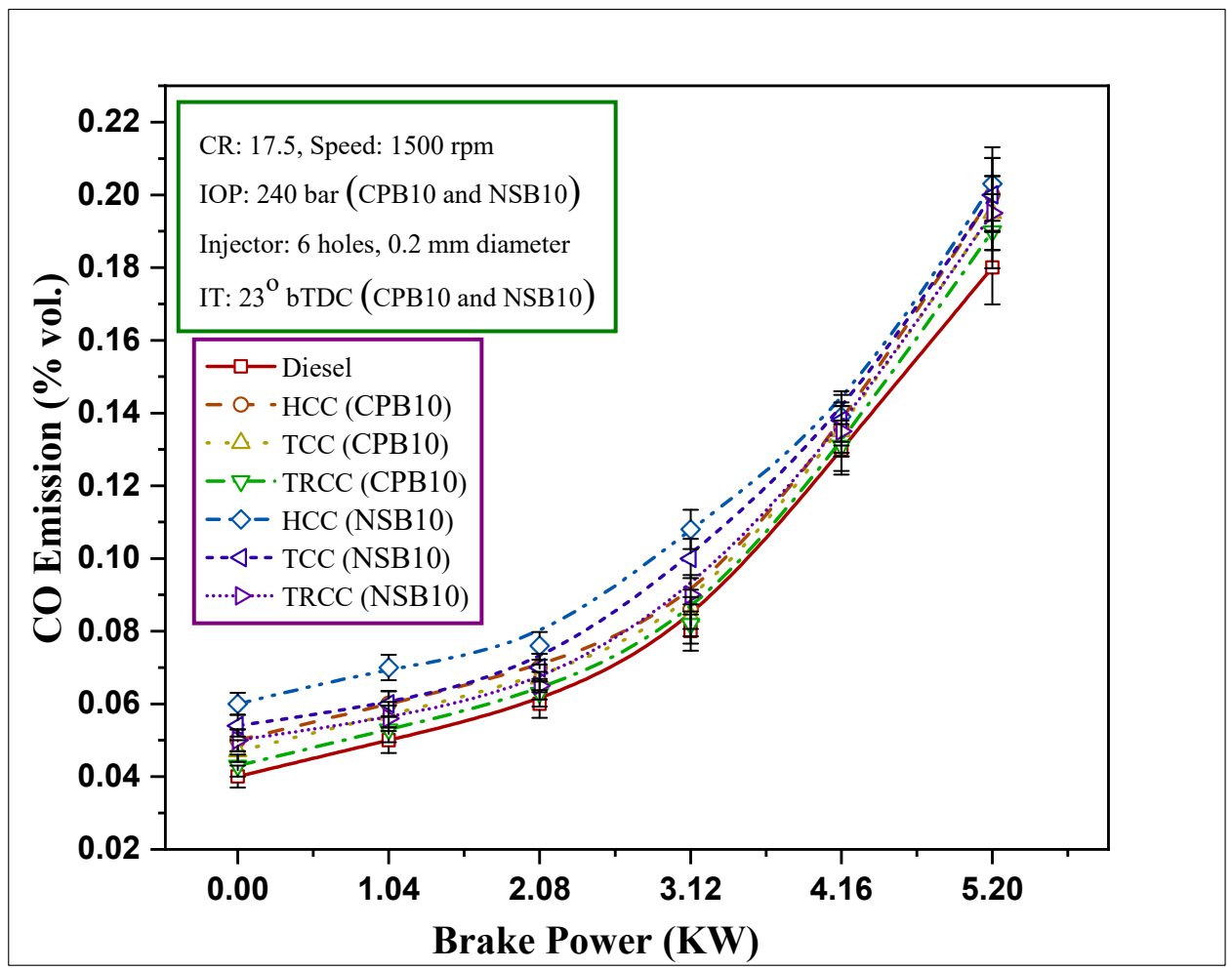

Figure 11. CO Emission variation at various $C C$ shapes and BP.

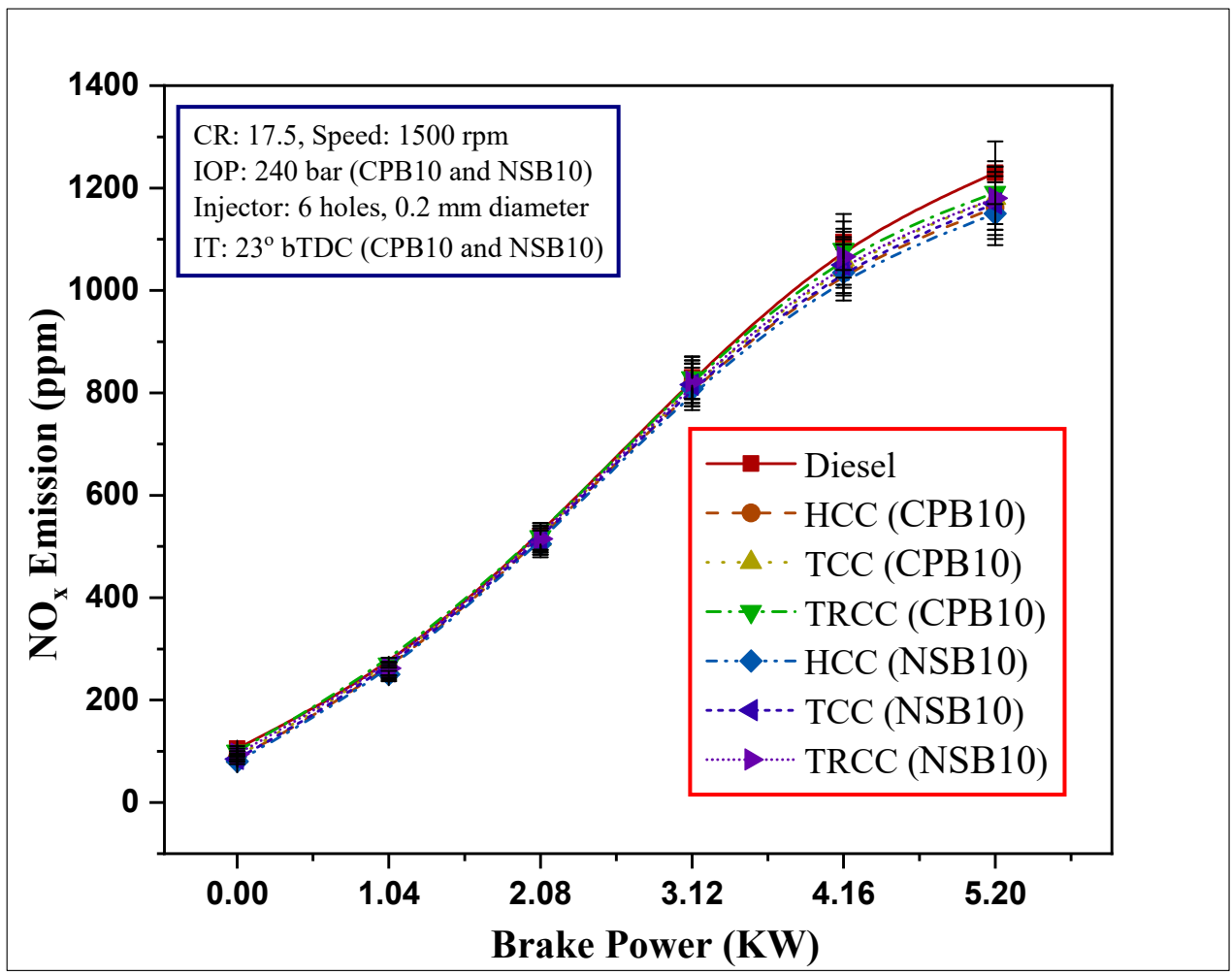

Figure 12. NOx Emission variation at various CC shapes and BP.4.3.3. Parameters of Combustion. 


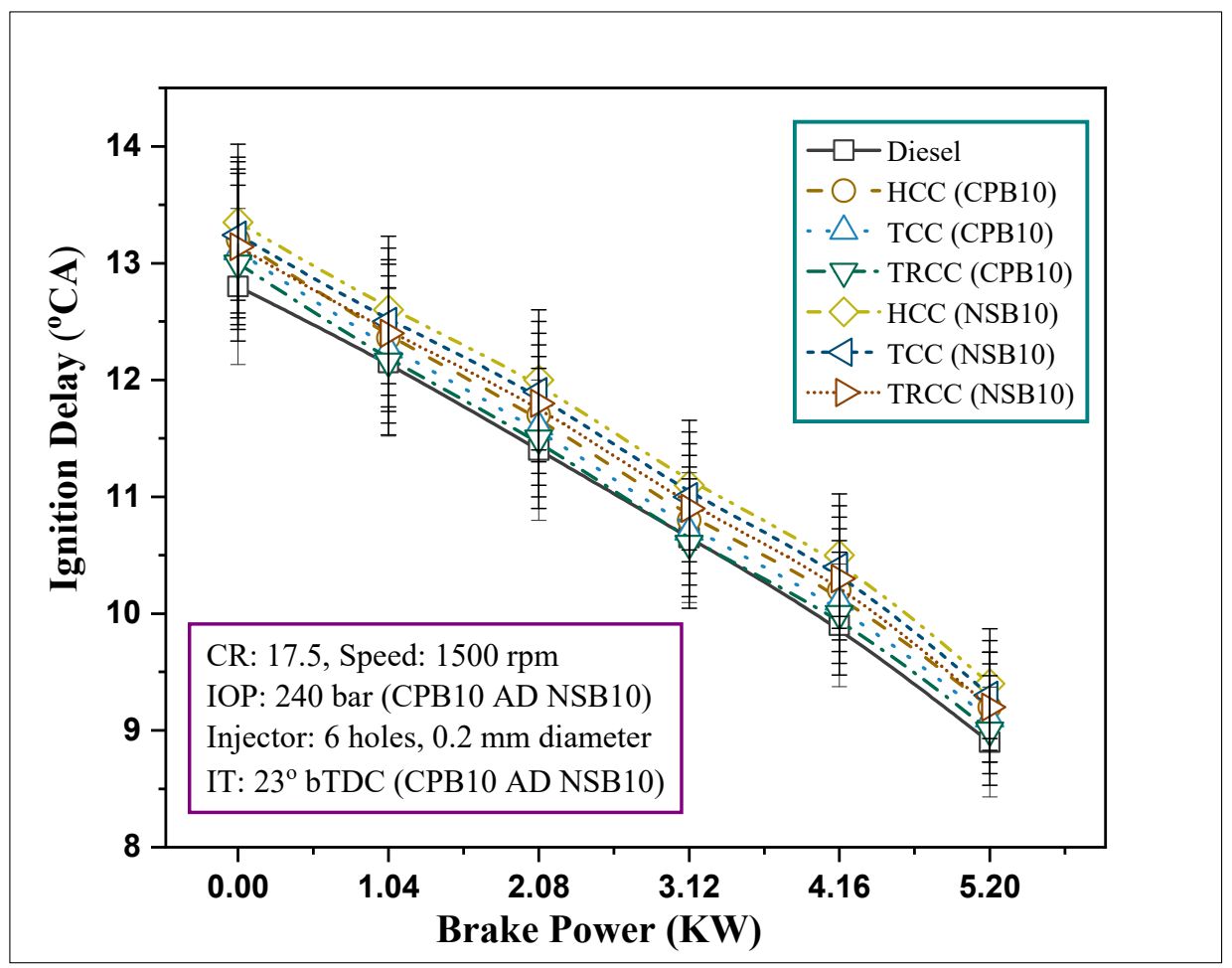

Figure 13. ID variation at various $C C$ shapes and BP.

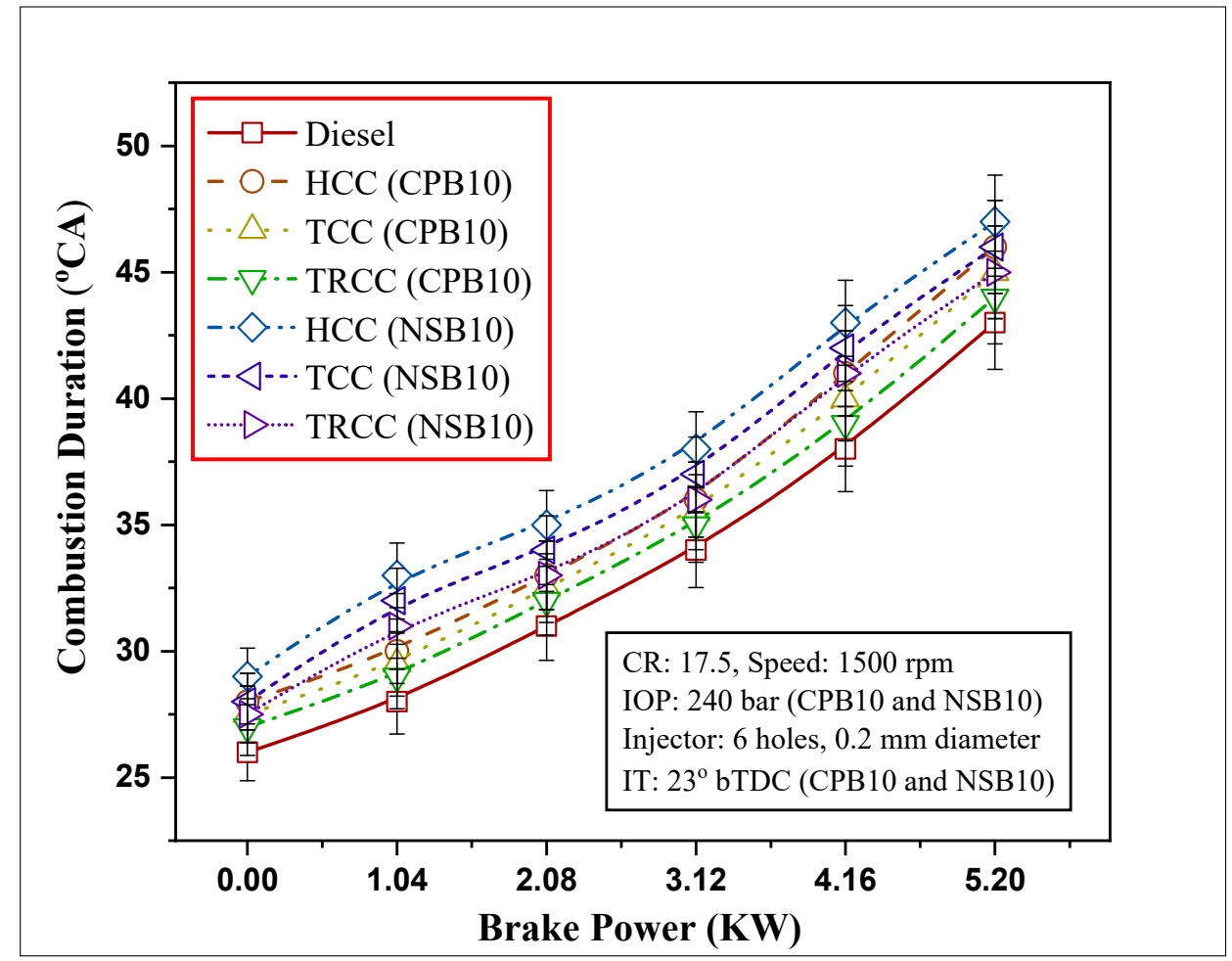

Figure 14. $C D$ variation at various $C C$ shapes and BP. 


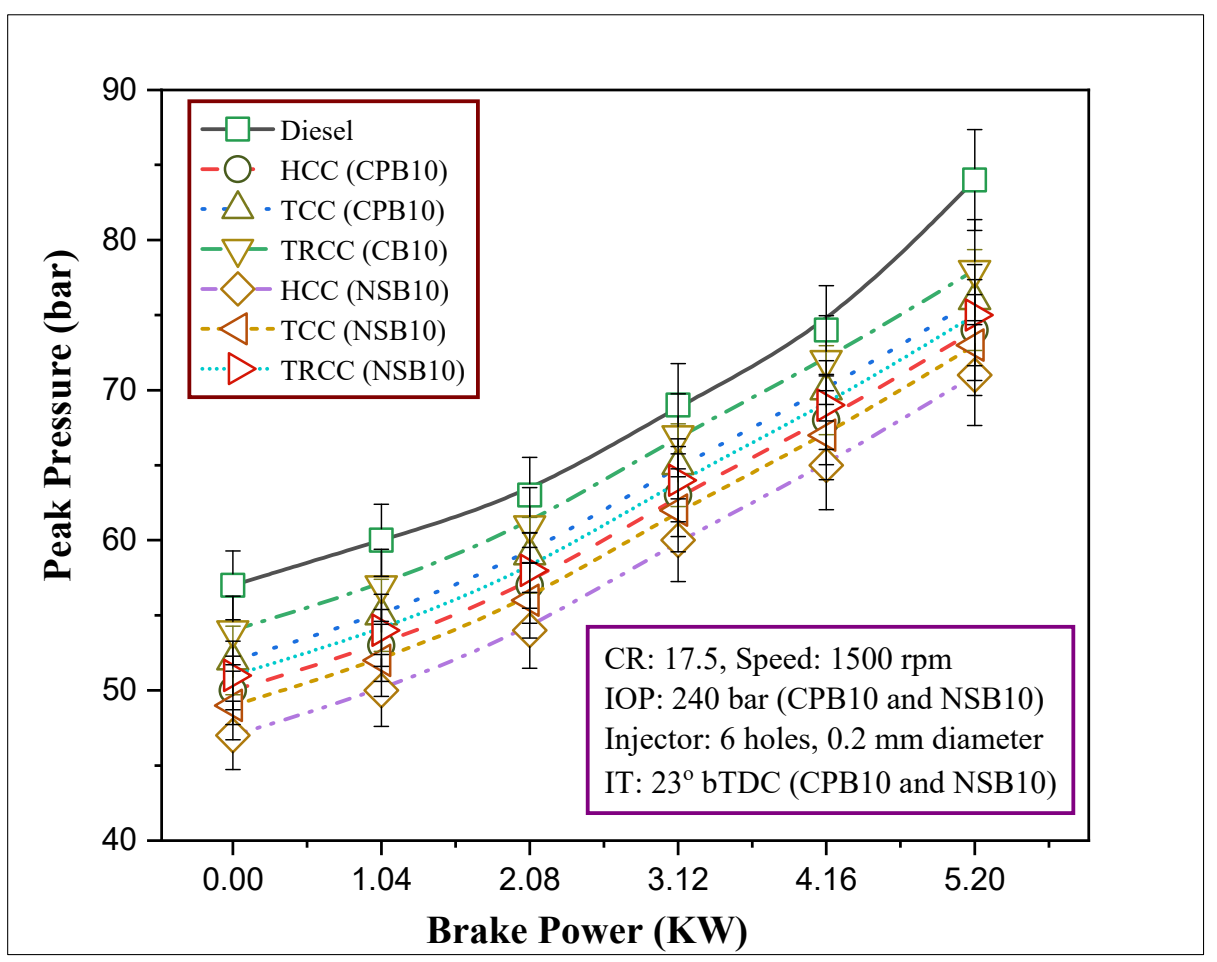

Figure 15. PP variation at various $\mathrm{CC}$ shapes and BP.

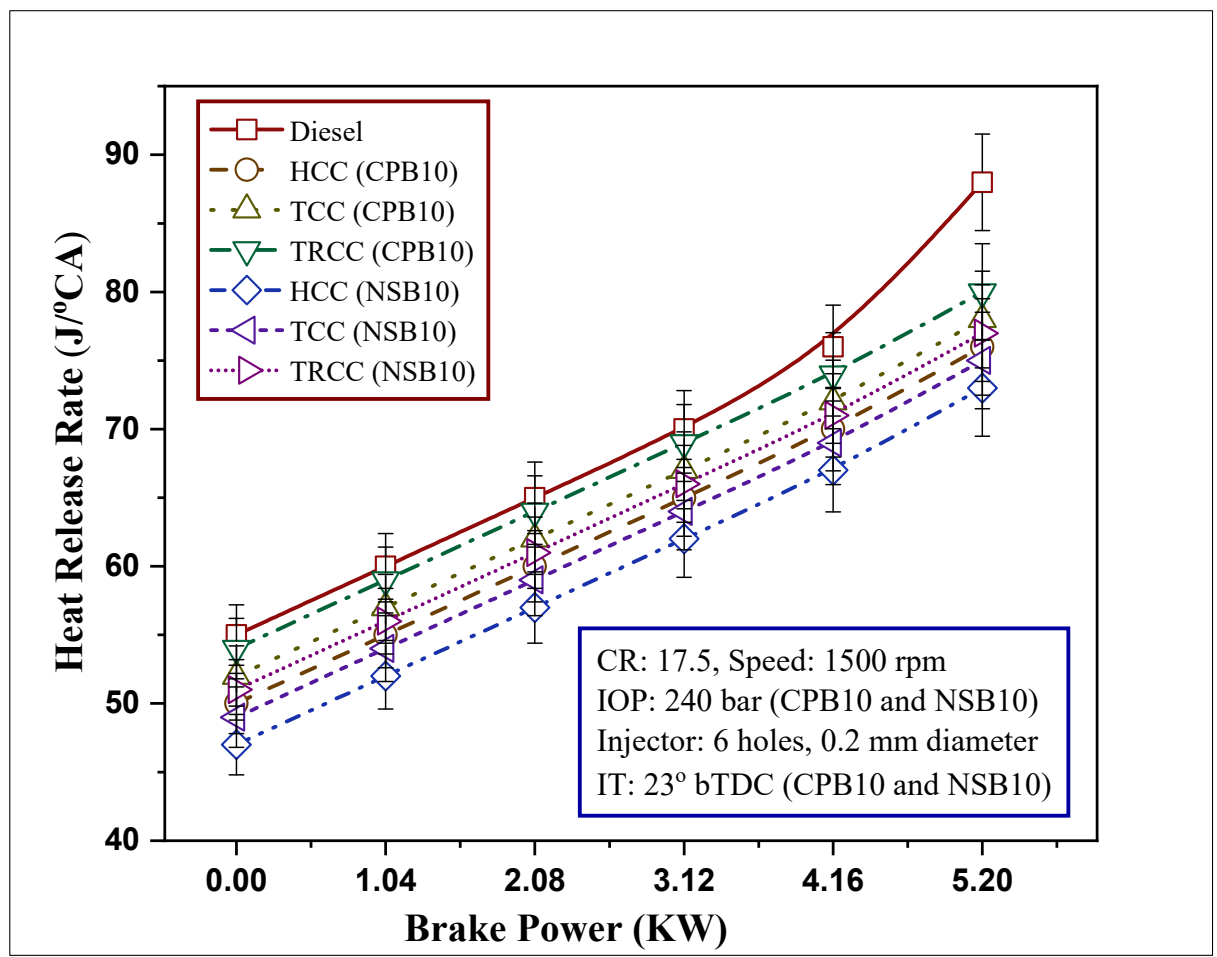

Figure 16. HRR variation at various $C C$ shapes and BP.

\subsubsection{Performance of Engine Brake Thermal Efficiency}

The BTE variation in a diesel engine driven by CPB10 and NSB10 with various CC shapes and BP is represented by Figure 8. TRCC endowed diesel engine driven by blended fuel exhibited prominent results comparatively with various CC shapes selected. TRCC prevents flame front propagation from spreading in the squish region; thereby, a better mixture formation, on account of better air motion, increased the swirl and tumble flow 
that yielded enhanced BTE. Higher BTE with TRCC shape can be due to the ability to guide the field of flow to the cylinder sub volumes.

\subsubsection{Exhaust Emissions}

The variations in the $\mathrm{CI}$ engine emission levels of hydrocarbons, smoke, carbon monoxide and NOx for varying CC shapes and BP are projected in Figures 9-12. Blends were observed to have higher $\mathrm{HC}, \mathrm{CO}$ and smoke emissions in comparison with diesel with all CC shapes. Adverse to this, NOx emissions for blends were low with all CC shapes. Owing to proper air-fuel mixing resulted by high turbulence, complete combustion with TRCC displayed results better than the other CC shapes and all BP [36]. A combined effect of high PP and HRR during the premixing phase of combustion at higher temperatures can produce the noticed trend.

Figure 9 provides the influence of the combustion chamber shape on smoke with both biodiesels. Diesel engine produced lower smoke emission with TRCC in comparison with other CC shapes used owing to a better mixing process inside the cylinder. Higher turbulence in the TRCC resulted in low heat losses and enhanced oxidation, thus reducing the combustion temperature and smoke emission. At $80 \%$ load, the engine exhibited approximately $5.1 \%$ to $9.5 \%$ lesser smoke with biodiesel in comparison with diesel operation.

The effect of CC shapes on HC and CO emissions are illustrated in Figures 10 and 11. TRCC resulted in lower $\mathrm{HC}$ and $\mathrm{CO}$ emissions owing to a lower ignition lag and higher HRR. The air motion in TRCC improved the mixture formation of both biodiesels and air, thus improving the overall combustion process and increasing both $\mathrm{HC}$ and $\mathrm{CO}$ emissions. Furthermore, owing to the better burning qualities, the CPB10 produced significantly reduced $\mathrm{HC}$ and $\mathrm{CO}$ emissions than the NSB10.

NOx changes with BP and different CC shape are provided in Figure 12. Diesel engine operation with both biodiesels showed elevated NOx at higher loads. Rapid combustion of fuel boosted the combustion process by reducing the ignition delay period that elevated the combustion temperature to yield higher Nox. The TRCC shape provided higher Nox emission, which may be caused by increased combustion temperatures owing to the enhanced combustion process as a result of improved mixture formation in TRCC. Furthermore, at $80 \%$ load the engine produced approximately $6 \%$ to $12 \%$ lower NOx with biodiesels contrasted with single (CI) mode [37].

Figures 13-16 specify the variation trend of ID, CD, PP and HRR at various CC shapes and BP. Static IT was used to calculate the ignition delay. The start of combustion was determined from the differentiated cylinder pressure variation time data where a sudden rise in the slope at the start of ignition on account of fast premixed heat release. The end of combustion was taken as the point where $90 \%$ of the heat release had occurred. Ignition delay (ID) is the time duration between the start of injection (SOI) and the start of ignition. SOI is the static fuel injection timing.

The graphs display a decreasing ID curve and an increasing CD trend at elevated BP and all CC shapes, which in the case of diesel as fuel are observed to be lower. The reason for this can be the rise in the temperature of gases inside the cylinder at higher BP. The ID and $C D$ with diesel were lower compared with blends with all CC shapes. Proper air-fuel mixture ensures effective combustion, which contributes to the rise in temperature and pressure, thereby resulting in higher HRR $[38,39]$. Lower trends were observed in TRCC for ID and CD at high PP and HRR for various CC shapes. Blend exhibited lower HRR in comparison with diesel owing to poor combustion potentials.

\section{Conclusions}

The outcomes of the modified direct transesterification (MDT) method of biodiesel extraction followed by the experimental work carried out on diesel engine operation with blends with different operating parameters can be summarized as follows: 
- Direct transesterification (DT) can be an optimum solution to the glycerine separation problem. The duration for chemical reaction is considerably reduced from $5 \mathrm{~h}$ to only $2 \mathrm{~h}$;

- The modified direct transesterification (MDT) eliminates problems associated with petroleum ether and blending;

- The diesel run engine provided $30.6 \%$ BTE at $23^{\circ}$ bTDC, 205 bar IOP and HCC at $80 \%$ load. The CPB10 fueled diesel engine provided a maximum BTE of $29.1 \%$ while the NSB10 fueled engine yielded a BTE of $28.4 \%$ with 240 bar IOP, a six-hole injector ( $0.2 \mathrm{~mm}$ orifice diameter) and TRCC shape;

- CO, HC, NOx and smoke for CPB10 were 0.09\%, 55 ppm, 1140 ppm and 48 ppm, respectively, whereas for NSB10 they were $0.11 \%, 59 \mathrm{ppm}, 1142 \mathrm{ppm}$ and $52 \mathrm{ppm}$, respectively, at $23^{\circ} \mathrm{bTDC}$ of injection timing, 240 bar IOP and $80 \%$ load, which are comparable with the diesel run engine at $23^{\circ} \mathrm{bTDC}, 205 \mathrm{bar}$ IOP and at $80 \%$ load. CO, $\mathrm{HC}, \mathrm{NOx}$ and smoke emissions for a diesel fuel engine at stated operating conditions are $0.1 \%, 40 \mathrm{ppm}, 1080 \mathrm{ppm}$ and $44 \mathrm{ppm}$;

- $\quad H R R$ in the NSB10 run engine was $73 \mathrm{~J} /{ }^{\circ}$ crank angle, the CPB10 run engine was $76 \mathrm{~J} /{ }^{\circ}$ crank angle at $23^{\circ}$ bTDC of injection timing, 240 bar IOP and $80 \%$ load. Whereas $78 \mathrm{~J} /{ }^{\circ}$ crank angle for diesel engine at $23^{\circ} \mathrm{bTDC}, 205 \mathrm{bar}$ IOP and at $80 \%$ load;

- The maximum combustion pressure inside the cylinder for CPB10 was 72 bar and NSB10 was 70 bar at $23^{\circ}$ bTDC, 240 bar IOP and at $80 \%$ load. Whereas for diesel it was 75 bar at $23^{\circ}$ bTDC, 205 bar IOP and at $80 \%$ load.

Overall, it can be concluded that the engine operation with CPB10 and NSB10 at $23^{\circ}$ bTDC fuel injection timing, 240 bar IOP with TRCC can yield better results close to a diesel run engine at $23^{\circ} \mathrm{bTDC}$ fuel injection timing, 205 bar IOP with HCC.

Author Contributions: Conceptualization, T.M.Y.K. and S.V.K.; methodology, T.M.Y.K. and M.E.M.S.; validation, I.A.B., S.K. and I.M.; formal analysis, M.A.M.; investigation, T.M.Y.K.; writing-original draft preparation, T.M.Y.K.; writing-review and editing, S.V.K.; I.M. and N.H.; supervision, T.M.Y.K.; project administration, T.M.Y.K., I.A.B.; funding acquisition, I.A.B. All authors have read and agreed to the published version of the manuscript.

Funding: Scientific Research Deanship at King Khalid University and the Ministry of Education in KSA through the project number IFP-KKU-2020/1.

Institutional Review Board Statement: Not applicable.

Informed Consent Statement: Not applicable.

Data Availability Statement: Not applicable.

Acknowledgments: The authors extend his appreciation to the Scientific Research Deanship at King Khalid University and the Ministry of Education in KSA for funding this research work through the project number IFP-KKU-2020/1).

Conflicts of Interest: The authors declare no conflict of interest.

\section{Nomenclature}

CPB10 Ceiba pentandra biodiesel $10 \%$ and Diesel $90 \%$

NSB10 Nigella sativa biodiesel $10 \%$ and Diesel $90 \%$

NSME Nigella sativa methyl ester (Biodiesel)

CPME Ceiba pentandra methyl ester (Biodiesel)

TRCC Torriodal re-entrant combustion chamber

HCC Hemisperical combustion chamber

HSU Hartridge smoke unit

IOP Injector opening pressure

NOx Oxides of nitrogen

$\mathrm{CO}$ Carbon monoxide

HC Hydrocarbon 


$\begin{array}{ll}\text { CD } & \text { Combustion duration } \\ \text { ID } & \text { Ignition delay } \\ \text { HRR } & \text { Heat release rate } \\ \text { PP } & \text { Peak pressure } \\ \text { bTDC } & \text { Before top dead centre } \\ \text { CR } & \text { Compression ratio } \\ \text { IT } & \text { Injection timing } \\ \text { DT } & \text { Direct transesterification } \\ \text { MDT } & \text { Modified direct transesterification } \\ \text { TCC } & \text { Trapezoidal combustion chamber }\end{array}$

\section{References}

1. Mohan, B.; Yang, W.; Raman, V.; Sivasankaralingam, V.; Chou, S.K. Optimization of biodiesel fueled engine to meet emission standards through varying nozzle opening pressure and static injection timing. Appl. Energy 2014, 130, 450-457. [CrossRef]

2. Khan, T.Y.; Atabani, A.; Badruddin, I.A.; Badarudin, A.; Khayoon, M.; Triwahyono, S. Recent scenario and technologies to utilize non-edible oils for biodiesel production. Renew. Sustain. Energy Rev. 2014, 37, 840-851. [CrossRef]

3. Singh, S.; Singh, D. Biodiesel production through the use of different sources and characterization of oils and their esters as the substitute of diesel: A review. Renew. Sustain. Energy Rev. 2010, 14, 200-216. [CrossRef]

4. Griffiths, M.; Van Hille, R.P.; Harrison, S.T.L. Selection of Direct Transesterification as the Preferred Method for Assay of Fatty Acid Content of Microalgae. Lipids 2010, 45, 1053-1060. [CrossRef] [PubMed]

5. Khan, T.M.Y.; Badruddin, I.A.; Ankalgi, R.; Badarudin, A.; Hungund, B.; Ankalgi, F.R. Biodiesel production by direct transesterification process via sequential use of Acid-Base catalysis. Arab. J. Sci. Eng. 2018, 43, 5929-5936. [CrossRef]

6. Khan, T.M.Y. Direct Transesterification for Biodiesel Production and Testing the Engine for Performance and Emissions Run on Biodiesel-Diesel-Nano Blends. Nanomaterials 2021, 11, 417. [CrossRef]

7. Surya, K.; Tushar, A.; Sumita, D.; Biplab, D. Effect of fuel opening injection pressure and injection timing of hydrogen enriched rice bran biodiesel fuelled in CI engine. Int. J. Hydrog. Energy 2021, 46, 28789-28800.

8. Deokar, A.; Harari, P. Effect of injection pressure, injection timing and nozzle geometry on performance and emission characteristics of diesel engine operated with thevetia peruviana biodiesel. Mater. Today Proc. 2021. [CrossRef]

9. Shaik, M.S.; Dillip, K.M. Experimental investigations of dairy scum biodiesel in a diesel engine with variable injection timing for performance, emission and combustion. Fuel 2020, 280, 118647.

10. Ashok, B.; Nanthagopal, K.; Saravanan, B.; Somasundaram, P.; Jegadheesan, C.; Bhaskar, C.; Shivam, S.; Gaurang, P. A novel study on the effect lemon peel oil as a fuel in CRDI engine at various injection strategies. Energy Convers. Manag. 2018, 172, 517-528. [CrossRef]

11. Selvakumar, R.; Mahalakshmi, N.V. Influence of high pressure fuel injection system on engine performance and combustion characteristics of Moringa Oleifera biodiesel and its blends. Fuel 2020, 279, 118461.

12. Bora, B.J.; Saha, U.K. Optimisation of injection timing and compression ratio of a raw biogas powered dual fuel diesel engine. Appl. Therm. Eng. 2016, 92, 111-121. [CrossRef]

13. Karthica, S.V.; Senthil Kumara, M.; Nataraj, G.; Pradeep, P. An assessment on injection pressure and timing to reduce emissions on diesel engine powered by renewable fuel. J. Clean. Prod. 2020, 255, 120186. [CrossRef]

14. Raheman, H.; Ghadge, S.V. Performance of diesel engine with biodiesel at varying compression ratio and ignition timing. Fuel 2008, 87, 2659-2666. [CrossRef]

15. Channapattana, S.V.; Abhay, A.P.; Prashant, G.K. Investigation of DI-CI four stroke VCR engine at different fuel injection timing using bio-fuel derived from non-edible oil source as a fuel. Biofuels 2016, 7. [CrossRef]

16. Jindal, S.; Nandwana, B.; Rathore, N.; Vashistha, V. Experimental investigation of the effect of compression ratio and injection pressure in a direct injection diesel engine running on Jatropha methyl ester. Appl. Therm. Eng. 2010, 30, 442-448. [CrossRef]

17. Puhan, S.; Jegan, R.; Balasubbramanian, K.; Nagarajan, G. Effect of injection pressure on performance, emission and combustion characteristics of high linolenic linseed oil methyl ester in a DI diesel engine. Renew. Energy 2009, 34, 1227-1233. [CrossRef]

18. Gumus, M.; Sayin, C.; Canakci, M. The impact of fuel injection pressure on the exhaust emissions of a direct injection diesel engine fueled with biodiesel-diesel fuel blends. Fuel 2012, 95, 486-494. [CrossRef]

19. Çelikten, I.; Koca, A.; Arslan, M.A. Comparison of performance and emissions of diesel fuel, rapeseed and soybean oil methyl esters injected at different pressures. Renew. Energy 2010, 35, 814-820. [CrossRef]

20. Nwafor, O.; Rice, G.; Ogbonna, A. Effect of advanced injection timing on the performance of rapeseed oil in diesel engines. Renew. Energy 2000, 21, 433-444. [CrossRef]

21. Ganapathy, T.; Gakkhar, R.; Murugesan, K. Influence of injection timing on performance, combustion and emission characteristics of Jatropha biodiesel engine. Appl. Energy 2011, 88, 4376-4386. [CrossRef]

22. Bari, S.; Yu, C.W.; Lim, T.H. Effect of Fuel injection timing with waste cooking oil as a fuel in a direct injection diesel engine. Proc. Inst. Mech. Eng. Part D J. Automob. Eng. 2004, 218, 93-104. [CrossRef]

23. Mani, M.; Nagarajan, G. Influence of injection timing on performance, emission and combustion characteristics of a DI diesel engine running on waste plastic oil. Energy 2009, 34, 1617-1623. [CrossRef] 
24. Qi, D.; Leick, M.; Liu, Y.; Chiafon, F.L. Effect of EGR and injection timing on combustion and emission characteristics of split injection strategy DI-diesel engine fueled with biodiesel. Fuel 2011, 90, 1884-1891. [CrossRef]

25. Banapurmath, N.R.; Tewari, P.G.; Hosmath, R.S. Effect of biodiesel derived from Honge oil and its blends with diesel when directly injected at different injection pressures and injection timings in single-cylinder water-cooled compression ignition engine. Proc. Inst. Mech. Eng. Part A J. Power Energy 2008, 223, 31-40. [CrossRef]

26. Balusamy, T.; Marappan, R. Effect of Injection Time and Injection Pressure on CI Engine Fuelled with Methyl Ester of Thevetia Peruviana Seed Oil. Int. J. Green Energy 2010, 7, 397-409. [CrossRef]

27. Sivakumar, P.; Sindhanaiselvan, S.; Gandhi, N.N.; Devi, S.S.; Renganathan, S. Optimization and kinetic studies on biodiesel production from underutilized Ceiba pentandra oil. Fuel 2013, 103, 693-698. [CrossRef]

28. Silitonga, A.; Masjuki, H.; Mahlia, T.M.I.; Ong, H.C.; Chong, W.T. Experimental study on performance and exhaust emissions of a diesel engine fuelled with Ceiba pentandra biodiesel blends. Energy Convers. Manag. 2013, 76, 828-836. [CrossRef]

29. Silitonga, A.; Ong, H.C.; Mahlia, T.; Masjuki, H.; Chong, W.T. Characterization and production of Ceiba pentandra biodiesel and its blends. Fuel 2013, 108, 855-858. [CrossRef]

30. Ong, H.C.; Silitonga, A.; Masjuki, H.; Mahlia, T.M.I.; Chong, W.T.; Boosroh, M. Production and comparative fuel properties of biodiesel from non-edible oils: Jatropha curcas, Sterculia foetida and Ceiba pentandra. Energy Convers. Manag. 2013, 73, 245-255. [CrossRef]

31. Khandal, S.; Banapurmath, N.; Gaitonde, V.; Hiremath, S. Paradigm shift from mechanical direct injection diesel engines to advanced injection strategies of diesel homogeneous charge compression ignition (HCCI) engines-A comprehensive review. Renew. Sustain. Energy Rev. 2017, 70, 369-384. [CrossRef]

32. Aghabarari, B.; Dorostkar, N.; Martinez-Huerta, M. Synthesis of biodiesel from Nigella sativa seed oil using surfactant-Brønsted acidic-combined ionic liquid as catalyst. Fuel Process. Technol. 2013, 118, 296-301. [CrossRef]

33. Khan, T.M.Y.; Atabani, A.; Badruddin, I.A.; Ankalgi, R.; Khan, T.M.; Badarudin, A. Ceiba pentandra, Nigella sativa and their blend as prospective feedstocks for biodiesel. Ind. Crop. Prod. 2015, 65, 367-373. [CrossRef]

34. Khan, T.M.Y.; Badruddin, I.A.; Badarudin, A.; Banapurmath, N.R.; Salman Ahmed, N.J.; Quadir, G.A.; Al-Rashed, A.A.A.A.; Khaleed, H.M.T.; Kamangar, S. Effects of engine variables and heat transfer on the performance of biodiesel fueled IC engines. Renew. Sustain. Energy Rev. 2015, 44, 682-691. [CrossRef]

35. Akkoli, K.; Banapurmath, N.; Shivashimpi, M.; Soudagar, M.E.M.; Badruddin, I.A.; Alazwari, M.A.; Yaliwal, V.; Mujtaba, M.; Akram, N.; Goodarzi, M.; et al. Effect of injection parameters and producer gas derived from redgram stalk on the performance and emission characteristics of a diesel engine. Alex. Eng. J. 2021, 60, 3133-3142. [CrossRef]

36. Khandal, S.; Banapurmath, N.; Gaitonde, V. Effect of exhaust gas recirculation, fuel injection pressure and injection timing on the performance of common rail direct injection engine powered with honge biodiesel (BHO). Energy 2017, 139, 828-841. [CrossRef]

37. Sudershan, B.G.; Kamoji, M.; Rampure, P.B.; Banapurmath, N.R.; Khandal, S.V. Experimental Studies on the Use of Pyrolysis Oil for Diesel Engine Applications and Optimization of Engine Parameters of Injection Timing, Injector Opening Pressure and Injector Nozzle Geometry. Arab. J. Sci. Eng. 2017, 43, 4517-4530. [CrossRef]

38. Lava, K.; Sannagoudra, J.; Ganesh, D. Experimental exploration on the influence of different piston geometry and injection timing by using bio-diesel. Mater. Today Proc. 2017, 4, 10879-10885. [CrossRef]

39. Manjunath, N.; Rajashekhar, C.R.; Khan, T.M.Y.; Badruddin, I.A.; Kamangar, S.; Khandal, S.V. Augmented Turbulence for Progressive and Efficient Combustion in Biodiesel-Diesel Engine. Arab. J. Sci. Eng. 2019, 44, 7957-7966. [CrossRef] 